\title{
Development of an Inquiry-Based Science Learning Material Using Flash Card to Reduce Misconception of Elementary School Students
}

\author{
Intan Ika Ashhabul Mimanah', Suryanti' ${ }^{2}$, Nadi Suprapto ${ }^{3}$ \\ 1, 2,3Universitas Negeri Surabaya, Surabaya, Indonesia
}

\begin{tabular}{|c|c|}
\hline (A) Check for updates open 0 Access cc) (7) (2) & DOI: https://doi.org/10.46245/ijorer.v1i2.35 \\
\hline Sections Info & ABSTRACT \\
\hline Article history: & This study is development research with the aim \\
\hline Subm & cticality of inquiry-based learning tools assisted by \\
\hline Final Revised: July 16, 2020 & flashcard media to reduce misconceptions of elementary school students on \\
\hline Accepted: July 17, 2020 & light concept. Before and after the learning materials implemented, the pretest \\
\hline Published Online: July 31, 2020 & and posttest were carried out. Identification of students' misconceptions was \\
\hline Keyz & utilized by using the three-tiers diagnostic test. The data analysis technique \\
\hline Flashcard & used quantitative descriptive. The results of the study showed: (1) The validity \\
\hline Inquiry & of the learning materials was declared to be very valid by the validator, (2) \\
\hline Misconception & The practicality of the materials developed was declared practical by the \\
\hline 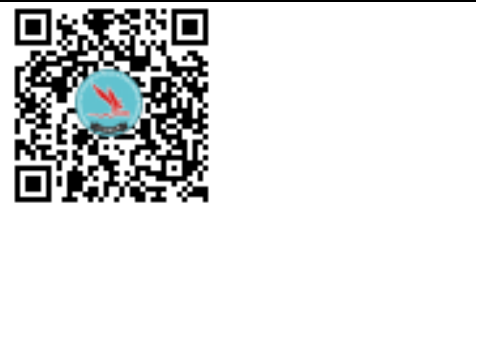 & $\begin{array}{l}\text { observer in terms of aspects of the device's implementation and student } \\
\text { activities in learning which were categorized very well, and (3) the } \\
\text { effectiveness of the learning materials being developed was declared effective } \\
\text { in terms of the application of the materials which had an impact on reducing } \\
\text { students' misconceptions which initially amounted to } 57.33 \% \text { down to } 17.33 \% \text {. } \\
\text { An Inquiry-based science learning device assisted with flashcard media that } \\
\text { has been developed, was feasible with valid, practical, and effective criteria, } \\
\text { and also can be used to reduce science misconceptions on elementary students } \\
\text { on light material. }\end{array}$ \\
\hline
\end{tabular}

\section{INTRODUCTION}

Science in elementary school is commonly called the Natural Sciences (IPA) subject. Natural Sciences (IPA) on the contents of the Curriculum 2013 is a subject that has an important role in developing all aspects of student abilities in the learning process that are developed by the fields of knowledge, attitudes, and skills, as well as the processes resulting from these aspects. very important in developing the abilities, attitudes, and skills of students. Besides, Science is also seen as a collection of empirical, theoretical, and practical knowledge about the natural world, produced by scientists who emphasize observations, explanations, and predictions of phenomena in the real world. Koballa (2010) defines the nature of science as a philosophical foundation that includes a body of knowledge, a way of thinking, a way of investigating, and its interaction with technology and. The Development of an Inquiry-Based Science Learning Material Using Flash Card to Reduce Elementary School Student Misconception in Learning about Light society. Natural science is not merely a collection of knowledge that produces a product in the form of laws, theories, postulates, principles, and concepts related to formulas, symbols, and units, but the product of science is obtained through a process of inquiry, and interact with the environment.

The above is in line with the guidelines in the Curriculum 2013 of Natural Sciences (Kemdikbud, 2014) also states that the Natural Sciences are (1) the process of obtaining information through the empirical method; (2) information obtained through an investigation that has been arranged logically and systematically; and (3) Science as a process or method of inquiry (inquiry methods) includes ways of thinking, attitudes, and steps of scientific activities to obtain scientific products, such as observation, 
measurement, formulating and testing hypotheses, collecting data, experimenting and predict. Because of the vast scope of the science material, students still often answer the tests given by the teacher in contrast to the concepts agreed upon by scientists. The assumption is that students have not mastered the concept well, or have concepts that are not the same as the actual concepts. so that it is difficult to use the concepts they have to explain various natural events, this is called misconception. One example is in light material

Misconceptions that often occur in elementary schools on the subject of light are (1) Brighter light moves faster, (2) in the process of seeing the eye emit light, (3) If the distance of the object to the eye gets closer, the object appears larger, (4) Draw normal lines, incident rays, and reflected rays, (5) Direction of incident rays opposite to reflected rays, (6) Shadows formed by concave mirrors are always reversed, (7) If light travels from a gas object to a liquid object, then the light will bend in water, (8) If the stick is put in water, or a pencil into a glass filled with water, then the stick/pencil looks bent because it is refracted, (9) mixing various colors (red, orange, green, indigo, purple) will produce white, (10) Is it true that the image formed by a lens that is halfclosed or closed at the middle or closed at the edges is also half (Ibrahim, 2012).

To reduce the false assumption earlier, it is necessary to have a capable device and a good strategy in learning. In this case, the author refers to Permendikbud No. 22 of 2016 concerning Process Standards, where every educator in the education unit is required to compile a complete and systematic lesson plan so that learning takes place interactively, inspiration, fun, challenging, efficient, motivating students to participate actively, and provide sufficient space for initiatives, ideas, creativity, and independence by the talents, interests and physical and psychological development of students.

In addition to tools that are by the curriculum, learning strategies are also needed to reduce students' misconceptions about the concept of science in learning. One strategy that can be felt overcome is based on inquiry. With inquiry, students are expected to be able to think critically about material assumptions that have not been by the symptoms that occur in the environment. The situation is the same as (Arends,2012), "inquirybased learning is one of the teaching models that has been developed to teaching students about how to think. The two main planning tasks required in inquiry-based learning are setting goals and identifying problems that are appropriate for inquiry. One of the objectives of inquiry learning is the reasoning skills of existing assumptions or problems".

The inquiry according to Aditomo et al. (2013) which describes six stages of learning; listen, get ready to find out, sort out, go further, make connections, and take action. Recently introduced to Victoria's main class is the 5E learning cycle model. Instructional model. While more commonly used in science education, the $5 \mathrm{E}$ learning cycle inquiry framework has five phases or domains of inquiry; engage, explore, explain, elaborate, and evaluate. The models for inquiry are designed to support class teachers in developing the progress of learning activities that help in the development of investigative and thinking skills. In this case, is finding concepts or problems that deviate from expert opinion. In addition to the existence of qualified learning tools and appropriate strategies in learning, interesting media are also needed to support and help reduce errors in assuming concepts in science material, especially light. This is because factual knowledge is knowledge of specific, detailed, and elementary facts that can be captured by the senses through the process of seeing, hearing, reading, or feeling. Thus, elementary school students need to be facilitated with something concrete 
to help understand knowledge. In line with Piaget's theory of learning, elementary school children (ages 7 to 12 years) have main characteristics: student knowledge is built through the use of physical objects and real experiences; failure to build knowledge with prospects without direct experience (Jaudah, 2005).

Because it is by Atkinson and Shiffrin's Memory Theory "through the process of attention, information moves to short-term memory, where it stays for 30 seconds or less unless it is trained. When information enters into long-term memory storage it can be retrieved during its lifetime" (Santrock, 2014). So by providing memorable learning, the learning will always be remembered and become a lifetime experience of students because it enters into the long-term memory. Thus the existence of learning media in $\mathrm{KBM}$ is very important, this is because the learning media are everything such as tools, environment, and all forms of activities that are conditioned to increase knowledge, change attitudes, or instill skills in everyone who uses it (Sanjaya, 2012). As for one of the concrete media that is considered capable of helping is the flashcard media. Where one of the functions of the flashcard (picture card) is to help students by helping students understand the lesson more concretely and to increase the activeness and learning outcomes of students (Daryanto, 2010). Besides the learning, media can be used to help students overcome misunderstandings in understanding the concept of light.

The theory supporting this research is the theory of cognitive development from Jean Piaget said that theory about how humans develop and understand and understand the world. From Piaget's perspective, humans always try to understand the environment, and their biological maturity, their interactions with the environment, and their social experiences combine to influence how they think about things. Arends (2012) explains the division of stages of cognitive development by Piaget, namely: 1) The Sensorimotor Stage (0-2 years) begins to recognize objects and can duplicate, 2) Preoperational Stages (2-7 Years), develops language acquisition, starts ability to think symbolically, can see from the perspective of others, do not have a logical mental operation at this stage, 3 ) Concrete Operational Stages (7-11 Years), can solve problems logically, can classify, 4) Formal Operational Stage (11 -15/adult) can solve various abstract problems. The Constructivism Learning Theory from Piaget and Vigotsky which emphasizes cognitive change occurs if concepts previously understood are processed with an imbalance process for understanding new information. The process of assimilation and accommodation in one's cognitive development is at the core of Piaget's constructivist theory. The main principle of Vogotsky's constructivist ideas is that: students learn by interacting with other people who are more capable, students are best at learning different concepts in their zone of proximal development, and students are given the complex and tangible tasks, and are helped to accomplish the task. Bruner's Learning The.

The three processes : (1) obtaining new information, (2) transforming information, and (3) testing the relevance and accuracy of knowledge (Bruner, 1973). New information can be in the form of refinement of previous information owned by someone or the information can be of such nature. so that it is contrary to the previous information possessed by someone (Dahar, 2002). which suggests that learning involves three processes that take place almost simultaneously. Where one's perception of an event is a constructive process. In this process, the person constructs a hypothesis by linking his sensory data to the model he has compiled about nature, then tests his hypothesis against the additional properties of the event. Atkinson and Shiffrin 
Memory Theory according to Atkinson-Shiffrin, memory involves a sequence of sensory memory, short memory, and long memory stages. Where information is stored only briefly or instantly but there is also some is transferred to short-term memory, which can only be maintained for 30 seconds (or more with the help of training). Atkinson and Shiffrin claim that old information is stored in short-term memory through the use of exercise, the greater the chance is to enter long-term memory. This research is development research with the aim the knowing of validity, effectiveness, and practicality of inquiry-based learning tools assisted by flashcard media to reduce misconceptions of elementary school students on light concept.

\section{RESEARCH METHOD}

The research design used a one-group pretest-posttest design. The population was $4^{\text {th }}$ grade students of elementary schools in the city of Surabaya in the academic year 20192020. Data collection techniques in this study were observation, tests, and student questionnaire responses. The instrument developed by the researcher was in the form of a device validation sheet, an observation sheet for the implementation of the lesson plan, a student questionnaire response sheet, and an observation sheet during the learning process. The data analysis technique used by researchers in this study was descriptive analysis.

The test was conducted on 15 participants of $4^{\text {th }}$ grade elementary school students in the city of Surabaya in the second semester of the 2019-2020 school year. By taking students randomly in the class so that the results achieved will be more valid. The research instrument was in the form of tests and questionnaires as well as the implementation of the pretest and post-test at each stage tested. The research following inquiry syntax in Table 1.

Table 1. Syntax of inquiry learning.

\begin{tabular}{ll}
\hline \multicolumn{1}{c}{ Phase } & \multicolumn{1}{c}{ Teacher Activity } \\
\hline $\begin{array}{l}\text { Get attention and explain the inquiry } \\
\text { process }\end{array}$ & $\begin{array}{l}\text { The teacher asks students to prepare themselves to learn and } \\
\text { prepare the process for learning } \\
\text { The teacher presents a problem situation or discrepant event } \\
\text { (makes students think) } \\
\text { Present the existing problems }\end{array}$ \\
$\begin{array}{ll}\text { The teacher encourages students to present questions about } \\
\text { problem situations and make hypotheses and explain what is } \\
\text { to explain problems or events }\end{array}$ & $\begin{array}{l}\text { The teacher asks students how they can collect data and test } \\
\text { their hypotheses. }\end{array}$ \\
$\begin{array}{ll}\text { Encourage students to collect data to } \\
\text { test hypotheses }\end{array}$ & $\begin{array}{l}\text { The teacher uses inquiry in closing learning and formulating } \\
\text { conclusions and generalizations } \\
\text { Formulate explanations and/or } \\
\text { conclusions } \\
\text { Reflecting on the problem situation } \\
\text { and the thought process using inquiry } \\
\text { and reflect on the inquiry process that has been done }\end{array}$ \\
\hline
\end{tabular}

(Arends, 2012)

To find out the level of students' misconceptions, the test of tracking misconceptions on light material was given by giving ten questions related to the level of students' confidence in light material and this value does not affect the students' grades in school. each question was given three alternative answers to the level of confidence that must be filled honestly such as: Don't Know, Not Sure, and Sure. then students are asked to write down the reasons for choosing the answer. the results of these student answers 
will be processed into the main data in knowing the level of students' misconceptions of light material. As for the tracking instruments used are as follows:
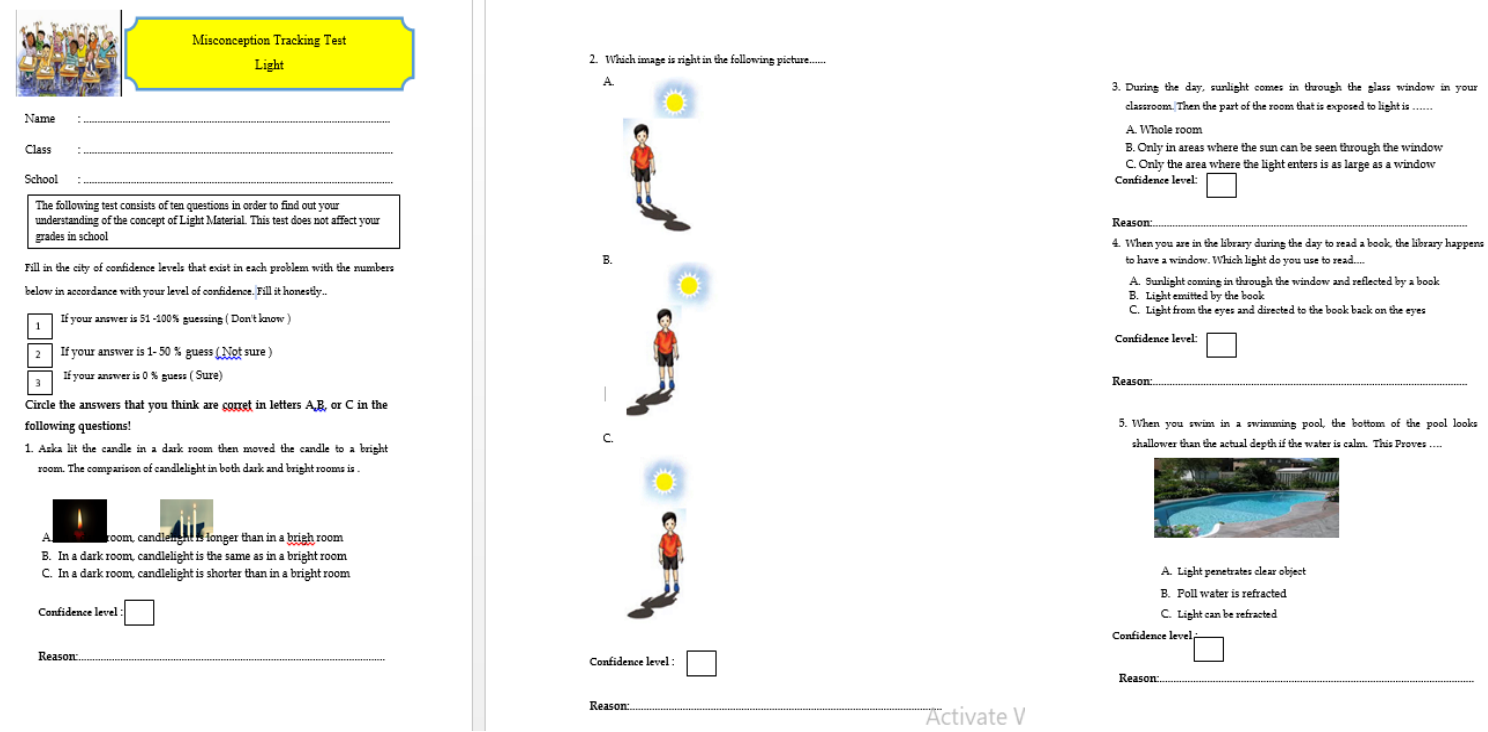

Figure 1. Misconception tracking test.

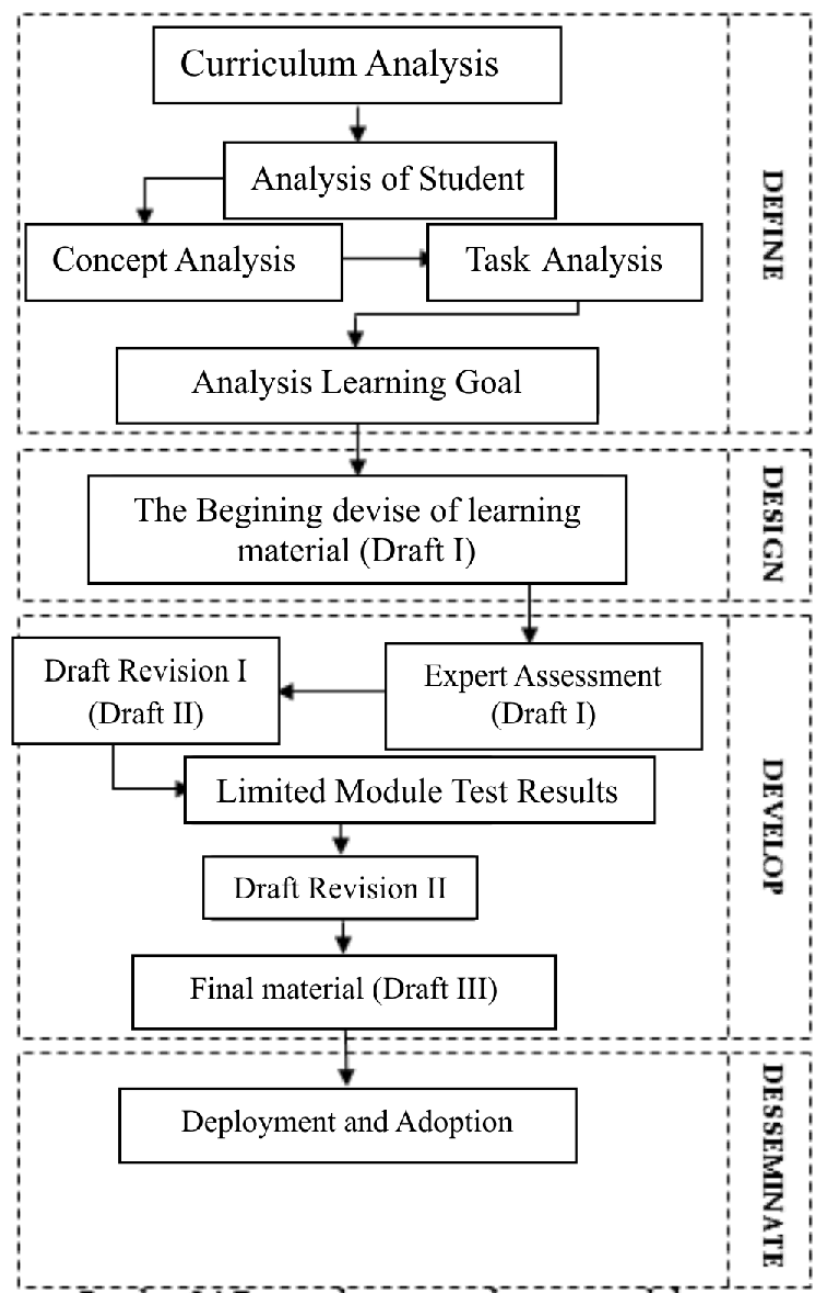

Figure 2. Four-D Model (Four-4 models). 
The research process by developing learning tools follows the development of $4 \mathrm{D}$ (Four-4 models) model devices adapted from Thiagarajan, which consists of 4 stages, namely (1) defining stage; (2) design phase; (3) development stage; (4) the deployment stage. However, the results of this study were not disseminated to other schools, so the fourth stage of the $4 \mathrm{D}$ model was not implemented because it only used 3 stages. The $4 \mathrm{D}$ model device development chart is shown in Figure 2.

Data analysis conducted in this study included a needs analysis, student analysis, task analysis, concept analysis, and formulation of learning objectives. Designing Phase At this stage the test preparation, media design, and initial design are carried out. The stages of device development were carried out from the results of the planning that has been prepared.

\section{RESULTS AND DISCUSSION}

To answer the problem formulation about the validity of learning tools by using inquiry strategies used validity analysis tools. The validity of learning tools includes Syllabus, lesson plans, Student Teaching Materials, Student Activity Sheet, diagnostic tests, and media.

Table 2. Validation of learning devices.

\begin{tabular}{cccc}
\hline \multirow{2}{*}{ Learning Tools } & \multicolumn{3}{c}{ Validation Result } \\
\cline { 2 - 4 } & Average & Modus & Category \\
\hline Syllabus & 3.3 & 3 & Good \\
\hline Lesson Plan & 3.3 & 3 & Good \\
\hline Handout & 3.0 & 3 & Good \\
\hline Worksheet & 3.0 & 3 & Good \\
\hline Media Flashcard & 3.1 & 3 & Good \\
\hline Misconception Test & 3.5 & 4 & \\
\hline
\end{tabular}

Table 2 shows the results of the development of learning tools developed by researchers suitable for use in learning. The feasibility of the device can be seen based on the results of the validity of the device that gets a valid category. To answer the formulation of the second problem concerning the practicality of learning tools based on inquiry use practical analysis of learning tools as follows.

Table 3. Implementation of lesson plans.

\begin{tabular}{lccc}
\hline \multirow{2}{*}{ Aspect } & \multicolumn{3}{c}{ IV } \\
\cline { 2 - 4 } & Average meeting & Modus & Criteria \\
\hline Pre Activities & 3.8 & 4 & Very good \\
\hline While Activities & 3.8 & 4 & Very good \\
\hline Post Activities & 3.5 & 3.5 & Very good \\
\hline Class situation & 3.8 & 4 & Very good \\
\hline Average implementation & 3.7 & 4 & Very good \\
\hline
\end{tabular}


Table 4. Obstacles to teaching and learning activities.

Constraints or Obstacles

Some students lack more understanding of the activities of developing hypotheses, analyzing data, and drawing conclusions

LKPD ( Student Activity Sheet) becomes a problem because students do not understand how to fill it

Learning inquiry requires a long time

Because learning is online, signal barriers and lack of knowledge of students and parents about online methods hamper inquiry learning.

This student activity was carried out very well as evidenced by the score of the activity accomplishment which reached 96\%. According to Ratumanan (2003), if the activity scores $\geq 90 \%$, then the activity can be concluded in the good category.

Table 5. Student activity.

\begin{tabular}{|c|c|c|c|c|c|c|c|c|}
\hline \multirow[t]{3}{*}{ Student Activity } & \multicolumn{7}{|c|}{ Frekuensi (\%) } & \multirow[t]{3}{*}{ Category } \\
\hline & \multicolumn{2}{|c|}{ Meeting I } & \multicolumn{2}{|c|}{ Meeting II } & \multicolumn{2}{|c|}{ Meeting III } & \multirow[t]{2}{*}{$\overline{\boldsymbol{x}}$} & \\
\hline & P1 & P2 & P1 & P2 & P1 & P2 & & \\
\hline $\begin{array}{l}\text { Listen to the teacher's } \\
\text { explanation }\end{array}$ & 100 & 78 & 100 & 100 & 100 & 100 & 96 & Very good \\
\hline $\begin{array}{l}\text { Reading teaching } \\
\text { material }\end{array}$ & 100 & 100 & 100 & 100 & 100 & 100 & 100 & Very good \\
\hline $\begin{array}{l}\text { Read flashcard media } \\
\text { material }\end{array}$ & 78 & 89 & 100 & 100 & 100 & 100 & 95 & Very good \\
\hline $\begin{array}{l}\text { Conducting activities } \\
\text { that create a } \\
\text { conducive learning } \\
\text { atmosphere }\end{array}$ & 78 & 89 & 89 & 89 & 89 & 100 & 89 & Good \\
\hline Formulate the problem & 100 & 100 & 78 & 89 & 78 & 100 & 91 & Very good \\
\hline Make a hypothesis & 100 & 100 & 100 & 100 & 100 & 100 & 100 & Very good \\
\hline $\begin{array}{l}\text { Gather data to test } \\
\text { hypotheses }\end{array}$ & 100 & 100 & 100 & 100 & 100 & 100 & 100 & Very good \\
\hline $\begin{array}{l}\text { Test the hypothesis } \\
\text { according to the data } \\
\text { collected }\end{array}$ & 100 & 100 & 100 & 100 & 100 & 100 & 100 & Very good \\
\hline Make conclusions & 89 & 78 & 89 & 89 & 89 & 100 & 89 & Good \\
\hline The implementation & 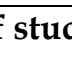 & & & & & & 96 & Very good \\
\hline
\end{tabular}

To answer the third problem formulation question about the effectiveness of learning tools using inquiry strategies the effectiveness of learning tools analysis is used as follows: 
Table 6. Reduction of student misconceptions.

\begin{tabular}{|c|c|c|c|c|c|c|}
\hline \multirow{2}{*}{$\begin{array}{l}\text { Question } \\
\text { Number }\end{array}$} & \multicolumn{2}{|c|}{ Pretest } & \multicolumn{2}{|c|}{ Post-test } & \multicolumn{2}{|c|}{ Reduction } \\
\hline & Total & $(\%)$ & $T$ & $(\%)$ & Total & $(\%)$ \\
\hline 1 & 13 & 86.67 & 4 & 26.67 & 9 & 60.00 \\
\hline 2 & 14 & 93.33 & 8 & 53.33 & 6 & 40.00 \\
\hline 3 & 9 & 60.00 & 2 & 13.33 & 7 & 46.67 \\
\hline 4 & 5 & 33.33 & 0 & 0.00 & 5 & 33.33 \\
\hline 5 & 9 & 60.00 & 0 & 0.00 & 3 & 20.00 \\
\hline 6 & 10 & 66.67 & 2 & 13.33 & 8 & 53.33 \\
\hline 7 & 8 & 53.33 & 0 & 0.00 & 8 & 53.33 \\
\hline 8 & 8 & 53.33 & 6 & 40.00 & 2 & 13.33 \\
\hline 9 & 12 & 80.00 & 2 & 13.33 & 10 & 66.67 \\
\hline 10 & 6 & 40.00 & 2 & 13.33 & 4 & 26.67 \\
\hline
\end{tabular}

Table 6 shows a comparison of data of students who experience misconceptions during the pretest and posttest. The profile of misconceptions after learning with the inquiry strategy assisted by flashcard media decreased the percentage of misconceptions at post-test. The reduction of misconceptions in the posttest occurred in ten-question concepts tested with different percentages. The highest reduction in misconception occurred in problem number 9 that tested the image of the mirror in a curved mirror with a percentage of $66.67 \%$, problem number 1 test about the nature of light can propagate straight by a percentage of $60.00 \%$. While the smallest percentage of misconception reduction occurred in question number 8 which tested the nature of the image on a flat mirror with a percentage of $13.33 \%$. Based on the discussion above it can be concluded that learning using inquiry-based learning tools assisted with flashcard media more reduces misconceptions on students compared to learning without using inquiry-based learning tools assisted by flashcard media. In the posttest, there are two problems whose misconceptions are well reduced, namely questions number 1 and 9.

Table 7. Normality test.

\begin{tabular}{lcccccc}
\hline \multicolumn{9}{c}{ Kosts of Normality $^{\circ}$} & \multicolumn{3}{c}{ Shapiro-Wilk } \\
\cline { 2 - 7 } & Statistic & Df & Sig. & Statistic & df & Sig. \\
\hline Pretest & .289 & 15 & .001 & .839 & 15 & .012 \\
\hline Posttest & .219 & 15 & .052 & .888 & 15 & .063 \\
\hline
\end{tabular}

a. Lilliefors Significance Correction

Table 7 shows that the pretest sig because the sample data is less than 50 then using the Shapiro-Wilk column. In the Shapiro-Wilk column, the value is $0.063>$ sig. 0.05 then the data is normally distributed or $H_{o}$ accepted.

Table 8. Paired T-Test.

\begin{tabular}{|c|c|c|c|c|c|c|c|c|c|}
\hline \multicolumn{10}{|c|}{ Paired Samples Test } \\
\hline & & \multicolumn{5}{|c|}{ Paired Differences } & \multirow{3}{*}{$t$} & \multirow{3}{*}{ df } & \multirow{3}{*}{$\begin{array}{l}\text { Sig. (2- } \\
\text { tailed) }\end{array}$} \\
\hline & & \multirow[t]{2}{*}{ Mean } & \multirow{2}{*}{$\begin{array}{l}\text { Std. } \\
\text { Deviati } \\
\text { on }\end{array}$} & \multirow{2}{*}{$\begin{array}{l}\text { Std. } \\
\text { Error } \\
\text { Mean }\end{array}$} & \multicolumn{2}{|c|}{$\begin{array}{c}95 \% \text { Confidence Interval of } \\
\text { the Difference }\end{array}$} & & & \\
\hline & & & & & Lower & Upper & & & \\
\hline $\begin{array}{c}\text { Pair } \\
1\end{array}$ & $\begin{array}{l}\text { Pretest - } \\
\text { Posttest }\end{array}$ & 4.533 & 2.10 & .542 & 3.37 & 5.696 & 8.361 & 14 & .000 \\
\hline
\end{tabular}

Based on Table 8, the average obtained for the number of misconceptions before and after inquiry-based learning using flashcard media is 4, the standard deviation is 2.100 with intervals of 5.696. T-test results are 5.696, this shows that the value of $t$ is greater 
than 2.56, so it is accepted at a significant $95 \%$. If sig. : $\mathrm{p} \leq 0.01$ then there is a difference with a significant level of $5 \%$. T count $8.3361 \mathrm{t}$ table 2.262 and the significance value 0.00 $<0.005$. This means and is accepted, which means the average number of students' misconceptions between after learning with inquiry-based learning devices assisted by flashcard media significantly decreases compared to before learning by using inquirybased learning devices assisted by flashcard media on light material.

Table 9. Calculation of N-Gain.

\begin{tabular}{llccccl}
\hline \multicolumn{1}{c}{ Initial Student } & \multicolumn{2}{c}{ Pre-test } & \multicolumn{2}{c}{ Post-test } & N-Gain \\
\hline APPH & 20 & TT & 80 & T & 0.75 & High \\
\hline AHS & 20 & TT & 70 & T & 0.63 & Enough \\
\hline AIM & 20 & TT & 70 & T & 0.63 & Enough \\
\hline AAM & 20 & TT & 70 & T & 0.63 & Enough \\
\hline DAM & 10 & TT & 90 & T & 0.89 & High \\
\hline ANR & 30 & TT & 90 & T & 0.86 & High \\
\hline GMMM & 30 & TT & 70 & T & 0.57 & Enough \\
\hline MT & 30 & TT & 90 & T & 0.86 & High \\
\hline RABK & 10 & TT & 90 & T & 0.89 & High \\
\hline RBNA & 20 & TT & 60 & TT & 0.50 & Enough \\
\hline SSA & 30 & TT & 80 & T & 0.71 & High \\
\hline TC & 30 & TT & 40 & TT & 0.14 & Low \\
\hline VS & 0 & TT & 80 & T & 0.80 & High \\
\hline VDP & 10 & TT & 80 & T & 0.78 & High \\
\hline ZPA & 0 & TT & 80 & T & 0.80 & High \\
\hline TT: Not Passed; T; Passed & & & & & &
\end{tabular}

Based on N-Gain calculations, there are 9 high category students and 5 medium category students. The average yield of N-Gain is 0.70 based on N-Gain criteria of high category

Table 10. Individual completeness.

\begin{tabular}{ccccc}
\hline Student & Pretest & $\begin{array}{c}\text { Minimum Mastery } \\
\text { Criteria }=\mathbf{7 0}\end{array}$ & Posttest & $\begin{array}{c}\text { Minimum Mastery } \\
\text { Criteria }=\mathbf{7 0}\end{array}$ \\
\hline APPH & 20 & Failed & 80 & Done \\
\hline AHS & 20 & Failed & 70 & Done \\
\hline AIM & 20 & Failed & 70 & Done \\
\hline AAM & 20 & Failed & 70 & Done \\
\hline DAM & 10 & Failed & 90 & Done \\
\hline ANR & 30 & Failed & 90 & Done \\
\hline GMMM & 30 & Failed & 70 & Done \\
\hline MT & 30 & Failed & 90 & Done \\
\hline RABK & 10 & Failed & 90 & Done \\
\hline RBNA & 20 & Failed & 60 & Failed \\
\hline SSA & 30 & Failed & 80 & Foiled \\
\hline TC & 30 & Failed & 40 & Done \\
\hline VS & 0 & Failed & 80 & Done \\
\hline VDP & 10 & Failed & 80 & Done \\
\hline ZPA & 0 & Failed & 80 &
\end{tabular}

The results of completeness analysis individually on the pretest and posttest. Completeness of individuals at the pretest nothing is complete in learning. While in the 
posttest completeness of the student as many as 13 students were declared complete and as many as 2 students were declared incomplete. The results of the classical class completeness analysis were $86.67 \%$. This proves that classical completeness is achieved. According to the Ministry of Education and Culture (2014) completeness of the class is said to be competent if the number of students who have finished learning $>85 \%$ of the total number of students.

Table 11. Success indicators of student.

\begin{tabular}{|c|c|c|c|c|c|c|c|c|c|}
\hline \multirow{2}{*}{ Student } & \multicolumn{7}{|c|}{ Indicators } & \multirow{2}{*}{ Total } & \multirow{2}{*}{ Percentage } \\
\hline & 1 & 2 & 3 & 4 & 5 & 6 & 7 & & \\
\hline APPH & 0 & 0 & 0 & 1 & 0 & 0 & 2 & 3 & 30 \\
\hline AHS & 0 & 0 & 0 & 1 & 0 & 0 & 2 & 3 & 30 \\
\hline AIM & 0 & 0 & 0 & 1 & 0 & 0 & 0 & 1 & 10 \\
\hline AAM & 0 & 0 & 0 & 1 & 0 & 0 & 0 & 1 & 10 \\
\hline DAM & 0 & 0 & 0 & 1 & 0 & 0 & 0 & 1 & 10 \\
\hline ANR & 0 & 0 & 0 & 1 & 0 & 1 & 1 & 3 & 30 \\
\hline GMMM & 0 & 0 & 1 & 0 & 1 & 1 & 0 & 3 & 30 \\
\hline MT & 0 & 0 & 0 & 1 & 0 & 0 & 1 & 2 & 20 \\
\hline RABK & 0 & 0 & 0 & 0 & 1 & 0 & 0 & 1 & 10 \\
\hline RBNA & 0 & 0 & 0 & 0 & 1 & 1 & 0 & 2 & 20 \\
\hline SSA & 0 & 0 & 1 & 0 & 0 & 1 & 1 & 3 & 30 \\
\hline TC & 0 & 0 & 1 & 1 & 0 & 0 & 0 & 2 & 20 \\
\hline VS & 0 & 0 & 0 & 0 & 0 & 0 & 0 & 0 & 0 \\
\hline VDP & 0 & 0 & 0 & 0 & 1 & 0 & 0 & 1 & 10 \\
\hline ZPA & 0 & 0 & 0 & 0 & 0 & 0 & 0 & 0 & 0 \\
\hline Total & 0 & 0 & 3 & 8 & 4 & 4 & 7 & 26 & $17 \%$ \\
\hline
\end{tabular}

The results of achieving the concept understanding indicator cover 7 aspects that were tested on 15 students, namely there were no students who were able to answer indicators 1 and 2, 3 students could work on indicator 3, 8 students were able to answer indicator 4 , each 4 could work on indicator 5 and indicators 6 , and 7 students can answer indicator 7. The researcher sets the Minimum Mastery Criteria (KKM) achievement indicator $\geq 70$ by the indicators set by the school. The average student who can answer the pretest with seven indicators is $17 \%$. Data on student responses to teaching and learning activities with inquiry-based learning assisted by flashcard media was obtained by using a questionnaire of responses provided to students after participating in learning activities. The recapitulation results of student responses are listed in the following Table 12.

Table 12. Student responses.

\begin{tabular}{|c|c|c|}
\hline \multirow[t]{2}{*}{ Aspect } & \multicolumn{2}{|c|}{$\begin{array}{l}\text { Percentage } \\
(\%)\end{array}$} \\
\hline & Yes & No \\
\hline $\begin{array}{l}\text { Students' opinions on the components of the lesson content, teaching materials, flash card } \\
\text { media, learning atmosphere, and the way the teacher teaches. }\end{array}$ & $99 \%$ & $1 \%$ \\
\hline $\begin{array}{l}\text { Students' understanding of the components of the lesson content, teaching materials, } \\
\text { flash card media, learning atmosphere, and the way the teacher teaches. }\end{array}$ & $93 \%$ & $7 \%$ \\
\hline Student's opinion if the next subject uses Inquiry-based teaching material. & $87 \%$ & $13 \%$ \\
\hline $\begin{array}{l}\text { Students' opinions about the way the teacher explains learning and the way the teacher } \\
\text { guides and experiment. }\end{array}$ & $100 \%$ & $0 \%$ \\
\hline Students' opinions about the ease of answering misconception test items. & $93 \%$ & $7 \%$ \\
\hline Presents of student response & $94 \%$ & $6 \%$ \\
\hline
\end{tabular}


Based on Table 12, the percentage of each statement is obtained. From the 5 questionnaire statements, an average of $\% 94 \%$ was obtained with a very positive category. Therefore, from the table exposure data, it means that students are enthusiastic about the teaching delivered and the learning becomes meaningful and memorable for students. In line with the research of Roida \& Maya (2013) that there is an influence of inquiry learning methods on mathematical learning outcomes. There is an interaction effect between inquiry learning methods and learning creativity on student mathematics learning outcomes. There is a significant effect between inquiry learning outcomes with conventional method learning outcomes. In this case, the use of the inquiry method is believed to be able to improve students' understanding and learning outcomes. Hidayati (2017) Said that the science process skills of students who have low critical thinking skills after being given inquiry learning models get higher results when compared to students who use problem-solving learning models. It can be concluded that the inquiry learning model can be applied to improve students' science process skills. The reduction of students' misconceptions by using inquiry learning methods has also been investigated by Edy (2014). With the results of data analysis obtained an average percentage of students' misconceptions in the pretest and posttest get 0.045 results with calculations using the Binomial test. This proves that there was a significant change in students' misconceptions. So remediation using an effective guided inquiry model to correct students' misconceptions.

The use of physical objects that can be used in reducing students' misconceptions on light material includes the use of flashcard media. Empit (2010) said the learning process using flashcard media to improve students' English vocabulary skills on the subject of listening and speaking vocabulary about the names of animals in class II A MI Ar-Rochman can take place effectively, this can be seen from the teacher and student activities during the learning activities take place. The use of flashcard media can make it easier for teachers to deliver learning materials and for students to increase the vocabulary of students and make learning fun and motivated children to participate actively in learning activities so that positive interaction occurs between teachers and students, students and students and students with learning media. Hariz \& Hasan (2019) concluded that flashcard media is one of the creative media that can be used to improve students' comprehension in mastering vocabulary, especially in Arabic lessons. The response or interest of students towards the field of Arabic studies can be stimulated by several methods and learning media that are interesting and efficient, one of which can be by using flashcard media. Rita \& Andi (2016) emphasized that the use of flash media that has been refined and tested has found excellent results and is suitable as a learning media for kindergarten B children both in large groups or small groups and may be used for the next level.

The use of flashcard media can improve the introduction of letter shapes in grade 1 students in Indonesian subjects at ABC Manado Schools. Also, students' interest in learning experienced a significant increase (Rachel \& Immanuel, 2017). Besides being able to be applied to early childhood use of flashcard media can also be applied to autistic children. This is reinforced by the results of a thesis from Ferina (2015) which says that the flashcard media is proven effective in increasing the ability to recognize members of the human body in autistic children in grade 2 elementary school in the special school of Autism Bina Anggita Yogyakarta. The flashcard media that had been developed were appropriate to be used as learning media in the fifth grade of elementary school and proved to be effectively used in learning science about the way 
plants adapt to their environment. The results of the thesis from Indah (2018) reinforce that the use of flashcard media is proven to improve the numeracy ability of grade I students in Rawa Laut 2 Primary School. There is a clear difference between students who have used flashcard media and students who have not used the media. Thus the flashcard media is considered effective in improving students' numeracy skills at Rawa Laut 2 Primary School Lampung. Seeing the results of some of the studies above and the data obtained by researchers, the use of the flash card-assisted inquiry method proves that teaching and learning activities become more meaningful so that students more easily understand the material being taught

\section{CONCLUSIONS}

Based on the results and discussion, it can be concluded that the inquiry-based learning device assisted with flashcard media that has been developed, was feasible with valid, practical, and effective criteria. And also it can be used to reduce science misconceptions on elementary students on light material. using this tool makes it easier for students to absorb the material being taught. For further research, this learning tool can be used and developed again in the Curriculum 2013.

\section{REFERENCES}

Aditomo, A., Goodyear, P., Bliuc, A., \& Ellis, R.A. (2013). Inquiry-based learning in higher education: Principle forms, educational objectives, and disciplinary variations. Studies in Higher Education, 38 (9), 1239-1258.

Arends, R. (2012). Learning to teach. New York: McGraw-Hill.

Bruner, J. (1973). The process of education. New York: Harvard University Press.

Dahar, R.W. (2002). Teori-teori belajar E pembelajaran. Bandung: Erlangga.

Daryanto. (2010). Media pembelajaran. Jakarta: Gava Media.

Edy S. (2014). Remediasi miskonsepsi siswa menggunakan model inkuiri terbimbing pada materi gerak rotasi di SMK. Jurnal Pendidikan dan Pembelajaran Khatulistiwa, $3(4), 1-13$.

Empit. H. (2010). Penggunaan media flashcard dalam meningkatkan kemampuan siswa pada pembelajaran kosa kata Bahasa inggris kelas 2 MI Ar-Rochman Samarang Garut. Jurnal Pendidikan Universitas Garut, 4(1), 10-18.

Ferina, K. (2015). Efektivitas media Flashcard terhadap kemampuan mengenal anggota tubuh manusia pada anak autis kelas 2 sekolah dasar di sekolah khusus Autis Bina Anggita Yogyakarta. Yogyakarta: Universitas Negeri Yogyakarta.

Hariz. Z., \& Hasan. (2019). Pengaruh Media Flash card terhadap penguasaan kosakata Bahasa arab. Jurnal AL Mi' Yar, 2(1), 41-55.

Hidayati, S. (2017). Model pembelajaran inquiry dan kemampuan berpikir kritis terhadap keterampilan proses sains siswa kelas 5 pada mata pelajaran IPA. Jurnal Pendidikan Dasar, 8(2), 1-12.

Ibrahim, M. (2012). Konsep, miskonsepsi, dan cara pembelajarannya. Surabaya: Unesa University Press.

Indah, P.S. (2018). Pengaruh media flashcard terhadap peningkatan kemampuan berhitung peserta didik kelas I sekolah dasar. Lampung: Universitas Negeri Lampung.

Jaudah, M.A. (2005). Mendidik anak secara Islam. Jakarta: Gema Insani Press

Kemdikbud. (2014). Permendikbud No.13 tentang pedoman pelaksanaan pembelajaran. Jakarta: Kemdikbud. 
Koballa, C. (2010). Science instruction in the middle and secondary schools developing fundamental knowledge and skill. United state of America: Pearson Education

Rachel, I.P.M., \& Imanuel, W.W.C. (2018). Penggunaan media flash card untuk meningkatkan pengenalan bentuk huruf siswa kelas I pada mata pelajaran Bahasa Indonesia di Sekolah ABC Manado. Jurnal Ilmu Pendidikan, 16(3), 305-313

Rita, K., \& Andi, M. (2016). Pengembangan Media Flash Card tema binatang untuk anak kelompok B di taman kanak-kanak Asemjajar-Surabaya. Jurnal Teknologi Pendidikan, 4(1), 24-32.

Roida, E.F.S., \& Maya N. (2013). Metode pembelajaran inquiry dan pengaruhnya terhadap hasil belajar matematika ditinjau dari kreativitas belajar. Jurnal Formativ, 2(1), 35-44.

Sanjaya, W. (2012). Media komunikasi pembelajaran. Jakarta; Kencana Prenada Media Group.

Santrock, J. (2014). Psikologi pendidikan. Jakarta: Salemba Humanika.

\footnotetext{
*Intan Ika Ashhabul Maimanah (Corresponding Author)

Basic Education Study Program, Postgraduate, Universitas Negeri Surabaya,

Jl. Kampus Lidah Unesa, Surabaya, East Java, 60213, Indonesia

Email: intan.18075@mhs.unesa.ac.id

Dr. Suryanti

Basic Education Study Program, Postgraduate, Universitas Negeri Surabaya, Jl. Kampus Lidah Unesa, Surabaya, East Java, 60213, Indonesia

Email: suryanti@unesa.ac.id

\section{Nadi Suprapto, Ph.D.}

Basic Education Study Program, Postgraduate, Universitas Negeri Surabaya, Jl. Kampus Lidah Unesa, Surabaya, East Java, 60213, Indonesia

Email: nadisuprapto@unesa.ac.id
} 